\title{
Preparation and Characterization of Caffeine Loaded Liposome and Ethosome Formulations for Transungual Application
}

\author{
Transungual Uygulama için Kafein Yüklü Lipozom ve Etazom \\ Formülasyonlarının Hazırlanması ve Karakterizasyonu
}

\author{
(D) Sakine TUNCAY TANRIVERDi \\ Ege University, Faculty of Pharmacy, Department of Pharmaceutical Technology, Izmir, Turkey
}

\begin{abstract}
Objectives: Nail plates have a structure that prevents transungual delivery of active agents. This situation makes it difficult to treat nail diseases. Materials and Methods: In this study, CF-loaded liposome and ethosome formulations were prepared for ungual application. Formulations were characterized by size, microscopic observation, $\mathrm{pH}$, and entrapment efficiency measurements. The effects of formulations and experimental conditions on nails were tested with characterization of nails before and after ex vivo permeation experiments.

Results: Microscopic observation confirmed the presence of spherical-structured vesicles. The particle sizes of vesicles were found as $545.3 \pm 0.121$ $\mathrm{nm}, 610.2 \pm 0.943 \mathrm{~nm}, 349.5 \pm 0.145 \mathrm{~nm}$ and $337.9 \pm 0.088 \mathrm{~nm}$ for liposomes (FI-FII) and ethosomes (FIII- FIV), respectively. The polydispersity index of particles was found under 0.5 , and the $\mathrm{pH}$ of formulations was around 7 . The encapsulation efficiency was found low due to the hydrophilic character of CF. Nail characterization studies showed that the experimental conditions had an effect on the nail plate.

Conclusion: The cumulative amount of drug after ex vivo permeation studies was found higher for ethosomes than for liposomes. The results confirm that liposomal systems could be promising systems for ungual drug delivery.
\end{abstract}

Key words: Transungual delivery, nail, liposome, ethosome, caffeine

öz

Amaç: Tırnak plağı, etken maddelerin tırnaktan geçişini engelleyen bir yapıya sahiptir. Bu durum tırnak hastalıklarının tedavisini zorlaştırmaktadır. Gereç ve Yöntemler: Bu çalışmada, ungual uygulama için CF yüklü lipozom ve etazom formülasyonları hazırlanmıştır. Formülasyonlar, yükleme kapasitesi, partikül boyutları, mikroskopik görüntülemesi, pH değerleri ile karakterize edilmiştir. Formülasyonların ve deneysel koșulların tırnaklar üzerindeki etkisi ex vivo geçiş çalışmaları öncesinde ve sonrasında yapılan tırnak karakterizasyonları ile test edilmiştir.

Bulgular: Mikroskobik inceleme veziküllerin dairesel yapısını konfirme etmiştir. Partikül boyutları lipozomlar (FI-FII) ve etazomlar (FIII-FIV) için sırasıyla, $545.3 \pm 0.121 \mathrm{~nm}, 610.2 \pm 0.943 \mathrm{~nm}, 349.5 \pm 0.145 \mathrm{~nm}$ ve $337.9 \pm 0.088 \mathrm{~nm}$ olarak bulunmuştur. Partiküllerin polidispersite indeksi $0.5^{\prime}$ in altında bulunmuştur ve formülasyonların pH'si 7 civarındadır. CF'nin hidrofilik karakterine bağı olarak yükleme kapasitesi düşük bulunmuştur. Tırnak karakterizasyon çalışmaları deneysel koşulların tırnak plağı üzerinde etkisi olduğunu göstermiştir.

Sonuç: Sonuç olarak, ex vivo geçiş çalışmaları sonucunda birikimli ilaç miktarı etazomlarda lipozomlardan daha fazla bulunmuştur. Sonuçlar, lipozomal sistemlerin ungual ilaç taşıyıcı sistemler olarak umut verici sistemler olduğunu doğrulamıştır.

Anahtar kelimeler: Transungual geçiş, tırnak, lipozom, etazom, kafein

*Correspondence: E-mail: sakinetuncay@windowslive.com, Phone: +90 5077039409 ORCID-ID: orcid.org/0000-0002-5716-0166

Received: 21.06.2017, Accepted: 21.09.2017

๑Turk J Pharm Sci, Published by Galenos Publishing House. 


\section{INTRODUCTION}

The human nail produces a strong, relatively inflexible nail plate, which is the most visible part of the nail apparatus.' The nail plate is derived from the epidermis but it is completely different in structure. In nail plates, keratin molecules are highly linked to disulfide bonds, which increase the thickness of the plates 100 times more than the epidermis. ${ }^{2,3}$ Nail plates have 80-90 layers of dead cells and consist of hard and soft-type keratin, water, and a small amount of lipid. ${ }^{4-6}$ Human nail plates behave like a hydrophilic gel membrane.17,8 The structure of the nail plate prevents effective ungual treatment of nail disorders because active agents cannot permeate through nail plates. ${ }^{9-13}$ In order to deliver a sufficient amount of active agent into and through the nail plate, the permeability of the nail plate to the drug needs to be enhanced.

Nail disorders can be treated with topical or oral therapies. Oral therapy, especially for fungal infections, has toxicity due to the long duration of treatment.1.14 As mentioned above, topical therapy is limited with low drug permeation through the nail plate.10,15 Therefore, patients are advised to apply formulations on the nail plate and surrounding tissue. Active drug can be eventually delivered through an alternative pathway, i.e., the surrounding skin above the nail plate, and the effectiveness is increased. In this approach, liposomes and ethosomes could be effective systems for transungual application of active agents. Liposomes are vesicular systems composed of phospholipids already present in the skin structure. Liposomes could enhance penetration of many drugs through the upper layer of the stratum corneum. Among their several possible pharmaceutic applications, they have been widely applied in topical drug delivery. ${ }^{16-19}$ Liposomes cannot be used as transdermal delivery systems due to their low penetration through the deeper skin layers. Therefore, vesicular systems such as ethosomes, transfersomes or niosomes are delivered from liposomes. Ethosomes are vesicular systems that contain high concentrations of ethanol. ${ }^{20}$ The presence of ethanol in systems of lipid vesicles influences penetration into the stratum corneum and the permeation of drugs. ${ }^{21}$ The ethosomal system is composed of phospholipids, ethanol, and water. Liposomes and ethosomes have a lipophilic character and could use lipophilic pathways in the nail plate; they could lead to more effective treatments of nail disorders. In the present study, caffeine (CF) was chosen as a model drug owing to its water soluble character, an relatively low molecular weight (194.2 g/ mol). CF-loaded liposome and ethosome formulations were prepared and formulations were characterized via encapsulation efficiency, particle size, and morphology. CF permeability through the human nail plate was examined. Thus, by comparison of the obtained permeability coefficients, the suitability of the formulations was evaluated. The effects of formulations and permeation conditions on human nail characteristics were studied and the most promising formulation is suggested.

\section{MATERIALS AND METHODS}

CF was purchased from Böhringer Ingelheim (Ingelheim am Rhein, Germany) and phosholipon $90 \mathrm{G}$ and lipoid S 100, were gifts from lipoid AG (Steinhausen Switzerland). Cholesterol was purchased from Sigma Company (St. Louis, USA). All other chemicals and reagents used in this study were of analytical grade or higher and were obtained commercially. In this work, nail samples were used for ex vivo permeation studies. The human cadaver nail samples were collected from human corpses that had been used in anatomy courses of Institute of Anatomy and Cell Biology, Freiburg, Germany. Therefore, ethics committee approval was not needed and was not taken.

\section{Preparation of liposomal formulations}

Liposomes were prepared using the thin film hydration method. ${ }^{18}$ Phospholipid, cholesterol and CF were dissolved in chloroform. Chloroform was then evaporated using a rotary evaporator (IKA RV10, Staufen, Germany) at $40{ }^{\circ} \mathrm{C}$ and $100 \mathrm{rpm}$. The flask was left under vacuum overnight to completely remove all traces of the solvent. The obtained thin film on the flask wall was hydrated with $10 \mathrm{~mL}$ phosphate-buffered saline (PBS, pH: 7.4). The liposomal suspension was homogenized using a polytron (Kinematica AG, Switzerland) at 13,000 rpm for $15 \mathrm{~min}$. The compositions of liposomes (FI and FII) are shown in Table 1.

\section{Preparation of ethosomal formulations}

Ethosomal formulations were prepared according to the ethanol injection method (Table 1, FIII and FIV). ${ }^{20}$ Phospholipid and CF were dissolved in ethanol and double-distilled water, respectively. The aqueous phase was added slowly to the lipid solution with constant stirring at $700 \mathrm{rpm}$. The system was kept at $30{ }^{\circ} \mathrm{C}$. The resulting vesicle suspension was homogenized using a polytron (Kinematica AG, Switzerland) at 13,000 rpm for $15 \mathrm{~min}$.

\section{Characterization of formulations}

The particle size and polydispersity index of the formulations were determined using a light scattering method with a Malvern Zetasizer 1000 HS (Malvern Instruments, England). The vesicular suspensions were diluted with PBS $(\mathrm{pH}: 7.4)$ for liposomes and $40 \%$ of the ethanol:water mixture for ethosomes before measuring particle size. The $\mathrm{pH}$ values of the formulations were determined using a pH meter (Jenway 3040 Ion Analyze) at $25 \pm 1^{\circ} \mathrm{C}$. All experiments were replicated

\begin{tabular}{|c|c|c|c|c|}
\hline Compositions & $\mathrm{FI}$ & FII & FIII & FIV \\
\hline Caffeine & $0.025 \mathrm{~g}$ & $0.025 \mathrm{~g}$ & $0.177 \mathrm{~g}$ & $0.174 \mathrm{~g}$ \\
\hline Lipoid S 100 & $0.222 \mathrm{~g}$ & & $0.15 \mathrm{~g}$ & $0.3 \mathrm{~g}$ \\
\hline Phospholipon $90 \mathrm{G}$ & & $0.222 \mathrm{~g}$ & & \\
\hline Cholesterol & $0.277 \mathrm{~g}$ & $0.277 \mathrm{~g}$ & & \\
\hline Chloroform & $12.5 \mathrm{~mL}$ & $12.5 \mathrm{~mL}$ & & \\
\hline Ethanol & & & $6 \mathrm{~g}$ & $6 \mathrm{~g}$ \\
\hline Water & & & $8.673 \mathrm{~g}$ & $8.526 \mathrm{~g}$ \\
\hline PBS (pH: 7.4) & $10 \mathrm{~mL}$ & $10 \mathrm{~mL}$ & & \\
\hline
\end{tabular}

PBS: Phosphate-buffered saline 
at least three times. The formulations were visualized using transmission electron microscopy (TEM) (Philips, Amsterdam) to confirm vesicular structure. The samples were negatively stained with a $1.5 \%$ aqueous solution of phosphotungstic acid. The vesicular suspensions were placed onto a carbon-coated copper grid and the excess solution was removed with a filter paper. The grid was left in room conditions for air-drying and then the films were observed on the TEM. The entrapment efficiency (EE) of both methods regarding CF was measured using the dialysis bag method. ${ }^{22-24}$ One milliliter of drugloaded liposomes and ethosome dispersions were dropped into a cellulose acetate dialysis bag (Spectra/Por ${ }^{\circledast}$, MW cut-off 12.000; Spectrum, Canada) immersed in $150 \mathrm{~mL}$ of water. The system was stirred at $400 \mathrm{rpm}$. After taking samples from the receiver solutions, fresh samples were added to obtain sink conditions. CF was spectrometrically assayed at $273 \mathrm{~nm}$ using an ultraviolet (UV)-spectrophotometer (UV-spectrophotometer DU720, Beckman Coulter, California, USA). The percent of encapsulation efficiency (EE \%) was calculated according to the following equation.

$E E \%=\frac{[\text { Total drug)-(diffused drug] }}{\text { [total drug] }} .100 \quad$ (Eq. 1)

\section{Preparations of nails}

Human cadaver nail samples were collected from human corpses that had been used in anatomy courses of Institute of Anatomy and Cell Biology, Freiburg, Germany. The whole nail plate collection technique was previously reported by Tuncay Tanrıverdi, 2013. ${ }^{25}$ Only "healthy" nail plates were taken for permeation studies. Nail samples were kept at $-20^{\circ} \mathrm{C}$.

\section{Characterization of nail samples}

The nail plates were left at room temperature overnight to equilibrate. Before starting the permeation experiments, the nail plates were weighed and the thickness of plates was measured with using digital micrometer (Digit cal SI, TESA S.A, Renens, Switzerland). Transonychial water loss (TOWL) was measured (Tewameter TM210, Courage\&Khazaka Electronic $\mathrm{GmbH}$, Germany) and Visioscan images (Visioscan VC98, Courage\&Khazaka Electronic GmbH, Germany) of the nail plates were taken. The nail plates were then immersed in PBS $(\mathrm{pH}$ : 7.4) for hydration. The characterization study was performed again after hydration in PBS and after the permeation studies. The nail plates were left to dry at room conditions after the permeation studies and characterization was performed one again.

\section{Nail permeation studies}

A nail adaptor was used to fix the nail plates on Franz diffusion cells with an area of $0.785 \mathrm{~cm}^{2}$. The acceptor chambers were filled with $5 \mathrm{~mL}$ of PBS (pH: 7.4), and $400 \mu \mathrm{L}$ of liposome and ethosome suspensions were added to the donor chamber. The receptor phase was constantly stirred using a magnetic stirrer at $400 \mathrm{rpm}$. The system was kept at $32{ }^{\circ} \mathrm{C}$ with a water bath and water jacket of the diffusion cells. Each day, a sample of
$400 \mu \mathrm{L}$ was taken from each cell over a period ten days and replaced with the same volume of PBS ( $\mathrm{pH}: 7.4)$ warmed to $32{ }^{\circ} \mathrm{C}$. The amount of drug in the sample was measured using a UV-spectrophotometer at $273 \mathrm{~nm}$. The permeability coefficient, $p(\mathrm{~cm} / \mathrm{s})$ was calculated from the CF flux in the steady state and the initially measured CF concentration of the applied formulation. The enhancement factor represents the permeability coefficient of a formulation divided by the permeability coefficient of ethanol: water and water solutions of CF such as a control. Thus, the possible enhancing effect of ethanol was eliminated. Additionally, the possible interference of ethanol on UV measurement was investigated and it was concluded that an enhancement factor did not notably change the results.

\section{RESULTS AND DISCUSSION}

\section{Characterization of formulations}

The CF-loaded liposomes and ethosomes (FI- FIV) were scanned using TEM and spherical structures were confirmed (Figure 1).

The particle size and the polydispersity of size distribution of the liposome and ethosome formulations measured by light scater are shown in Table 2. In accordance with other authors, the conventional liposomes showed a larger particle size and a higher polydispersity than the ethosomes. ${ }^{26}$ Statistical analyses [One-way ANOVA, post-hoc Tukey honest significant difference (HSD) test] showed that the particle size of all formulations were significantly different $(p<0.01)$. As reported by LópezPinto et al. ${ }^{24}$, ethanol confers a surface negative net charge to vesicles, which causes a decrease in the size of vesicles. The ability of the vesicles to entrap CF was investigated. EE was determined to be rather low according to the hydrophilic character of CF. Significant differences were observed between the four formulations (One-way ANOVA, post-hoc Tukey HSD test, p (0.01).

\section{Nail characterization}

The nails were characterized via, weight, thickness, Visioscan images, and TOWL. The nails were characterized before the nail

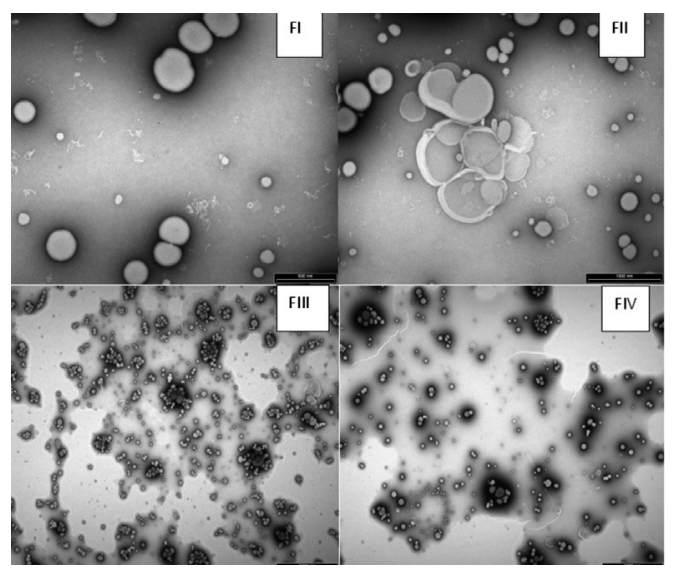

Figure 1. Transmission electron microscopy images of caffeine-loaded liposomes and ethosomes (FI, FII, FIII and FIV) 
permeation experiment. Then nails were immersed in PBS and characterized after being taking out from PBS. The parameters were tested after the permeation study, and finally, the nails were kept at room temperature to dry for $24 \mathrm{~h}$. After drying, the nail samples were characterized again. The weight of the nail plates increased after immersion in PBS for $1 \mathrm{~h}$. The percentage of weight increase was found as $23.89 \%$. The plates behave like a hydrophilic gel system. Therefore, plates could swell after immersion in solvent. However, $24 \mathrm{~h}$ after the experiment, the weight of nails decreased due to drying of the samples. It was concluded that the experimental conditions and room temperature could affect the weight of the nails. The thickness of the nails was also measured three times per nail. The nail thickness varies according to the person and the measured region as they are biological tissue. The nail samples were kept in PBS before the experiment. The sample thicknesses were re-measured after removal from PBS. The thickness of six nails increased, whereas the thickness of the other six nails decreased. The TOWL of the nails was measured before, after $1 \mathrm{~h}$ PBS immersion, after the experiment, and one day after the experiment. The results of TOWL are summarized in Table 3. The data showed that TOWL of the nails increased after $1 \mathrm{~h}$ immersion in PBS and after the experiment, as expected. On the day after the permeation experiment, the TOWL values of all nails decreased as was seen in the weight of nails. However, no correlation between TOWL and weight was found. This probably due to the decreasing water content during the 24 $h$, and then they became dry. The differences in TOWL can be partially assigned to the different thicknesses of the nail plates, as shown in Figure 2, where a relatively good correlation between thickness and TOWL was found before the permeation experiment.

The nail permeation experiments were continued for 10 days. During the experiments, the nails were treated with formulations and receptor phase at $32{ }^{\circ} \mathrm{C}$. A Visioscan VC 98 was used to evaluate nail surfaces before and after experiment. ${ }^{27}$ Figure 3 shows the dry surface of a nail plate before and $24 \mathrm{~h}$ after the experiment, which was treated with different formulations. The results showed that the application of liposomes and ethosomes induced a change of the superficial nail structure. Ethosomes had a greater effect on nail plates due to their high ethanol concentration.

\section{Nail permeation studies}

Table 4 shows the permeability coefficients and enhancement factors of the applied formulations. CF solutions in ethanol: water for ethosomes and in water for liposomes were used as control formulations. A significant improvement in permeability was found for both ethosomal formulations (One-way ANOVA, post-hoc Tukey HSD test, p 0.01 ). As expected, the molecular size of the vesicles had an inverse relationship with permeation through the nail plate (Figure 4). The ethanol/water solvents present in the system are suggested to hydrate the nail plate and

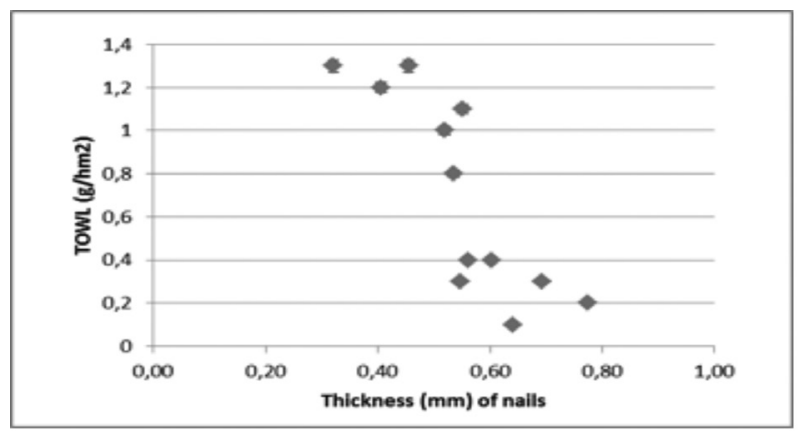

Figure 2. The influence of nail plate thickness on transonychial water loss

TOWL: Transonychial water loss

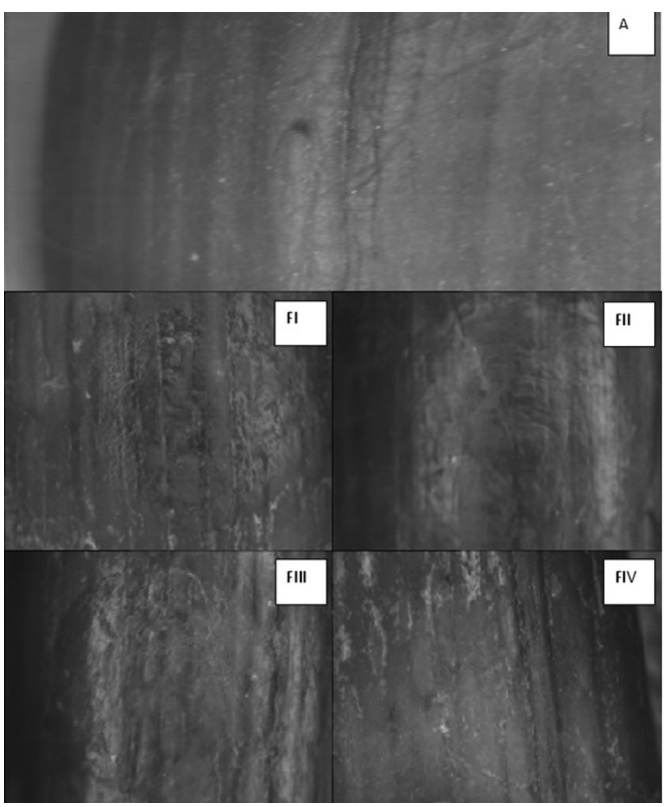

Figure 3. Visioscan images of nail before and after permeation experiment treated with FI-FIV formulations. A) The image of nail plate before the experiment

Table 2. Characterization of formulations

\begin{tabular}{lllll} 
& FI & FII & FIII & FIV \\
\hline Z-size $(\mathrm{nm})$ & $545.3 \pm 0.121$ & $610.2 \pm 0.943$ & $349.5 \pm 0.145$ & $337.9 \pm 0.088$ \\
\hline $\mathrm{PI}$ & $0.375 \pm 0.031$ & $0.253 \pm 0.034$ & $0.195 \pm 0.03$ & $0.249 \pm 0.074$ \\
\hline $\mathrm{EE}(\%)^{*}$ & $7.17 \pm 0.14$ & $16.95 \pm 0.21$ & $9.92 \pm 0.12$ & $18.40 \pm 0.63$ \\
\hline $\mathrm{pH}$ & $7.33 \pm 0.03$ & $7.33 \pm 0.02$ & $7.73 \pm 0.01$ & $7.79 \pm 0.01$ \\
\hline
\end{tabular}

*PI, represents the polydispersity index used as indication of size distribution of vesicles, EE: Encapsulation efficiency, PI: Polydispersity index 
Table 3. Transonychial water loss values of 12 nails

TOWL $\left(\mathrm{g} / \mathrm{hm}^{2}\right)^{*}$

\begin{tabular}{|c|c|c|c|c|c|c|c|c|c|}
\hline \multicolumn{5}{|c|}{ Liposome (FI-FII) } & \multicolumn{5}{|c|}{ Ethosome (FIII-FIV) } \\
\hline Nails & B.E* & A.PBS* & A.E.* & D.A.E. * & Nails & B.E* & A.PBS* & A.E.* & D.A.E.* \\
\hline 1 & $0.8 \pm 0.01$ & $6.6 \pm 0.04$ & $5.5 \pm 0.02$ & $0.9 \pm 0.01$ & 7 & $0.3 \pm 0.01$ & $7.1 \pm 0.03$ & $12.9 \pm 0.04$ & $0.2 \pm 0.01$ \\
\hline 2 & $1.3 \pm 0.02$ & $6.1 \pm 0.02$ & $11.8 \pm 0.01$ & $0.3 \pm 0.01$ & 8 & $0.4 \pm 0.03$ & $12.6 \pm 0.02$ & $12.3 \pm 0.05$ & $0.6 \pm 0.03$ \\
\hline 3 & $1.2 \pm 0.02$ & $8.9 \pm 0.03$ & $5.8 \pm 0.04$ & $0.6 \pm 0.02$ & 9 & $0.2 \pm 0.02$ & $5 \pm 0.02$ & $13.9 \pm 0.02$ & $0.3 \pm 0.02$ \\
\hline 4 & $1.3 \pm 0.01$ & $6.6 \pm 0.01$ & $7.6 \pm 0.05$ & $0.5 \pm 0.02$ & 10 & $0.4 \pm 0.05$ & $8.8 \pm 0.03$ & $16 \pm 0.01$ & $0.2 \pm 0.01$ \\
\hline 5 & $1 \pm 0.02$ & $8.5 \pm 0.01$ & $9.5 \pm 0.02$ & $0.8 \pm 0.01$ & 11 & $0.3 \pm 0.03$ & $4.5 \pm 0.05$ & $14.4 \pm 0.05$ & $0.1 \pm 0.01$ \\
\hline 6 & $1.1 \pm 0.01$ & $7 \pm 0.03$ & $15.9 \pm 0.06$ & $0.5 \pm 0.02$ & 12 & $0.1 \pm 0.01$ & $10.5 \pm 0.06$ & $18 \pm 0.03$ & $0.1 \pm 0.03$ \\
\hline
\end{tabular}

*B.E.: Before experiment, A.PBS: After immersing in phosphate-buffered saline for $1 \mathrm{~h}$, A.E.: After experiment, D.A.E.: Day after experiment,

TOWL: Transonychial water loss

Table 4. Permeability coefficient and enhancement factor of formulations and references

\begin{tabular}{lll} 
Formulations & $\begin{array}{l}\text { Permeability coefficient } \\
\left(\times 10^{-8} \mathrm{~cm} / \mathrm{s}\right)\end{array}$ & $\begin{array}{l}\text { Enhancement } \\
\text { factor }\end{array}$ \\
\hline $\mathrm{FI}$ & $3.4 \pm 2.007$ & 2.18 \\
\hline $\mathrm{FII}$ & $5.5 \pm 1.31$ & 3.53 \\
\hline FIII & $17.953 \pm 6.148$ & 10.20 \\
\hline FIV & $14.9 \pm 5.142$ & 8.47 \\
\hline Control CF-E/W & $1.56 \pm 0.85$ & 1.00 \\
\hline Control CF-W & $1.76 \pm 0.79$ & 1.00 \\
\hline CF: Caffeine & &
\end{tabular}

thus increase permeation of CF. Kobayashi et al..8 ${ }^{28}$ suggested that permeability through healthy and fungal nail plates is not significantly different. Thus, fungal nail permeability can be estimated from healthy nail permeability data. They also noted that the flux of drug through very heavily infected fungal nail plates might be higher than through healthy nail plates.

\section{CONCLUSION}

Nail disorders cannot be successfully treated with topical therapy due to the hard structure of nail plates. The nail plate is a barrier for the penetration of active substances. The aim of the study was to investigate the penetration enhancing effect of liposome and ethosome formulations for transungual delivery. CF was chosen as a hydrophilic drug. In this study, CF loaded liposomes and ethosomes were prepared for the first time for ungual application. Also, the effects of formulations and ex vivo permeation study conditions on nail plates were recorded via several parameters. CF was loaded with ethosomes and liposomes with low loading capacity because of the hydrophilic character of active agent. The particle size of ethosomes was found lower than liposomes. According to ex vivo studies, it was concluded that ethosomes had a greater penetration enhancing effect than liposomes. Finally, nail characterization studies showed that the experimental conditions had an effect on nail properties. As a conclusion, hydrophilic-drug-loaded liposome

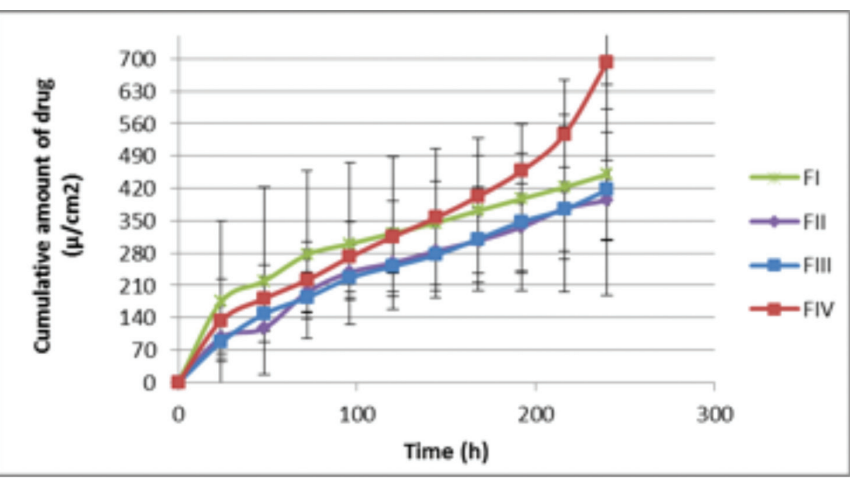

Figure 4. Cumulative amount of drug in receptor phase during the permeation experiment

and ethosome formulations were prepared and characterized. The results suggest that liposomes and ethosomes could enhance penetration of hydrophilic substances through nail plates and both systems can be used for topical treatment of nail disorders.

Conflict of Interest: No conflict of interest was declared by the authors.

\section{REFERENCES}

1. Murdan S. Drug delivery to the nail following topical application. Int J Pharm. 2002;236:1-26.

2. Walters KA, Flynn GL. Permeability characteristics of the human nail plate. Int J Cosmet Sci. 1983;5:231-246.

3. Gniadecka M, Faurskov Nielsen O, Christensen DH, Wulf HC. Structure of water, proteins, and lipids in intact human skin, hair, and nail. J Invest Dermatol. 1998:110:393-398.

4. Achten G, Andre J, Laporte M. Nails in light and electron microscopy. Semin Dermatol. 1991;10:54-64.

5. Murdan S. Enhancing the nail permeability of topically applied drugs. Expert Opin Drug Deliv. 2008;5:1267-1282.

6. Kobayashi Y, Miyamoto M, Sugibayashi K, Morimoto Y. Drug permeation through the three layers of the human nail plate. J Pharm Pharmacol. 1999;51:271-278. 
7. Walters KA, Flynn GL. Permeability characteristics of the human nail plate. Int J Cosmet Sci. 1983;5:231-246.

8. Garson JC, Baltenneck F, Leroy F, Riekel C, Müller M. Histological structure of human nails as studied by synchrotron $X$-ray microdiffraction. Cell Moll Biol. 2000;46:1025-1034.

9. Einarson TR, Gupta AK, Shear NH, Arikian S. Clinical and economic factors in the treatment of onychomycosis. Pharmacoeconomics. 1996;9:307-320.

10. Elewski BE. Onychomycosis: pathogenesis, diagnosis, and management. Clin Microbiol Rev. 1998;11:415-429.

11. Seebacher C. Action mechanisms of modern antifungal agents and resulting problems in the management of onychomycosis, Mycoses. 2003;46:506-510.

12. Hoogdalem EJV, Hoven WEV, Terspa IJ, Zijveld JV, Verschoor JSC, Visser JN. Nail penetration of the antifungal agent oxiconazole after repeated topical application in healthy volunteers, and the effect of acetylcysteine. Eur J Pharm Sci. 1997;5:119-127.

13. McAuley WJ, Jones SA, Traynor MJ, Guesné S, Murdan S, Brown MB. An investigation of how fungal infection influences drug penetration through onychomycosis patient's nail plates. Eur J Pharm Biopharm. 2016;102:178-184.

14. Repka MA, Mididoddi PK, Stodghill SP. Influence of human nail etching for the assessment of topical onychomycosis therapies. Int J Pharm. 2004;282:95-106.

15. Khengar RH, Jones SA, Turner RB, Forbes B, Brown MB. Nail swelling as a pre-formulation screen for the selection and optimisation of ungual penetration enhancers. Pharm Res. 2007;24:2207-2212.

16. Fresta M, Puglisi G. Application of liposomes as potential cutaneous drug delivery systems: in vitro and in vivo investigation with radioactivity labelled vesicles. J Drug Target. 1996;4:95-101.

17. Imbert D, Wickett RR. Topical delivery with liposomes. Cosmet Toiletries. 1995;110:32-46.
18. Bangham AD, Standish MM, Watkins JC. Diffusion of univalent ions across the lamellae of swollen phospholipids. J Mol Biol. 1965;13:238252.

19. Mezei M, Gulasekharam V. Liposomes--a selective drug delivery system for the topical route of administration: gel dosage form. J Pharm Pharmacol. 1982;34:473-474.

20. Touitou E, Dayan N, Bergelson L, Godin B, Eliaz M. Ethosomes - novel vesicular carriers for enhanced delivery: characterization and skin penetration properties. J Control Release. 2000;65:403-418.

21. Betz G, Aeppli A, Menshutina N, Leuenberger H. In vivo comparison of various liposome formulations for cosmetic application. Int J Pharm. 2005;296:44-54.

22. Mura P, Maestrelli F, González-Rodríguez ML, Michelacci I, Ghelardini C. Rabasco AM. Development, characterization and in vivo evaluation of benzocaine-loaded liposomes. Eur J Pharm Biopharm. 2007;67:86-95.

23. Foco A, Gasperlin M, Kristl J. Investigation of liposomes as carriers of sodium ascorbyl phosphate for cutaneous photoprotection. Int J Pharm. 2005;291:21-29.

24. López-Pinto JM, González-Rodríguez ML, Rabasco AM. Effect of cholesterol and ethanol on dermal delivery from DPPC liposomes. Int J Pharm. 2005;298:1-12.

25. Tanrıverdi ST, Özer Ö. Novel topical formulations of Terbinafine- $\mathrm{HCl}$ for treatment of onychomycosis. Eur J Pharm Sci. 2013;48:628-636.

26. Fang YP, Tsai YH, Wu PC, Huang YB. Comparison of 5-aminolevulinic acid-encapsulated liposome versus ethosome for skin delivery for photodynamic therapy. Int J Pharm. 2008;356:144-152.

27. Vejnovic I, Simmler L, Betz G. Investigation of different formulations for drug delivery through the nail plate. Int J Pharm. 2010;386:185-194.

28. Kobayashi Y, Komatsu T, Sumi M, Numajiri S, Miyamoto M, Kobayashi D, Sugibayashi K, Morimoto Y. In vitro permeation of several drugs through the human nail plate: relationship between physicochemical properties and nail permeability of drugs. Eur J Pharm Sci. 2004;21:471-477. 